\title{
The Diffrence of Weight Gain between DMPA Injection Contraceptive Users and Combinated Injection Contraceptive Users in Andalas Health Care Working Area
}

\author{
lin Prima Fitriah ${ }^{1}$ \\ Jurusan kebidanan Poltekkes Kemenkes Padang \\ ie2n85@yahoo.com
}

\section{Article Info}

\section{Article history}

Received date: 2019-11-04

Revised date: 2019-11-27

Accepted date: 2019-11-28

\begin{abstract}
The best known contraceptive method which is injectable contraception. But the rate of drop out using injection contraception is the second highest with a percentage of $28 \%$. The reason for discontinuation of injectable contraception is highest because acceptors are afraid of side effects. The purpose of this study was to determine differences in weight gain for users of DMPA injection contraception and combinations in the work area of Andalas Community Health Center, Padang City in 2019.This type of research is comparative analytic with a cross sectional study design. The study population was women of childbearing age in the Andalas Community Health Center working area who were actively using DMPA injections and combination injections. Samples were taken quota sampling as many as 62 people. Then analyzed by univariate and bivariate using thetestMann-Whitney. There was no significant difference in the mean increase in body weight between DMPA combined injection and injection KB acceptors in the work area of Andalas Community Health Center, Padang City in 2019 (Asymp. Sig 0.075 < of 0.05). The results of the study concluded that there was no significant difference in body weight gain between DMPA injection contraception users and combinations in the Andalas Community Health Center working area.
\end{abstract}

Keywords:

DMPA injection, combination injection, weight loss

\begin{abstract}
Abstrak
Metode kontrasepsi yang paling dikenal adalah kontrasepsi suntik. Namun tingkat putus penggunaan metode kontrasepsi suntik merupakan nomor dua tertinggi dengan persentase $28 \%$. Alasan putus pemakaian kontrasepsi suntik tertinggi karena akseptor takut efek samping. Salah satu efek samping yang cukup banyak dikeluhkan yaitu peningkatan berat badan. Tujuan penelitian ini untuk mengetahui perbedaan kenaikan berat badan pada pengguna alat kontrasepsi suntik DMPA dan kombinasi di wilayah kerja Puskesmas Andalas Kota Padang Tahun 2019.Jenis penelitian ini adalah analitik komperatif dengan desain Cross sectional study. Populasi penelitian adalah wanita pasangan usia subur di wilayah kerja Puskesmas Andalas yang aktif menggunakan suntik DMPA dan suntik kombinasi. Sampel diambil secara quota sampling sebanyak 62 orang. Kemudian dianalisis secara univariat dan bivariat menggunakan uji Mann- Whitney. Hasil penelitian disimpulkan tidak ada perbedaan yang signifikan kenaikan berat badan antara pengguna Alat Kontrasepsi suntik DMPA dan kombinasi di wilayah kerja Puskesmas Andalas.

KataKunci

Suntik DMPA, Suntik kombinasi, Penambahan Berat Badan
\end{abstract}




\section{PENDAHULUAN}

Undang-Undang No. 52 Tahun 2009 menyatakan tentang perkembangan kependudukan dan pembangunan keluarga, penduduk harus menjadi titik sentral dalam pembangunan berkelanjutan di Indonesia.' Keluarga Berencana (KB) merupakan salah satu pelayanan kesehatan yang paling dasar dan utama bagi wanita. Banyak wanita yang harus menentukan pilihan kontrasepsi yang sulit karena wanita harus menimbang berbagai faktor, termasuk status kesehatan mereka, efek samping potensial suatu metode, konsekuensi terhadap kehamilan yang tidak diinginkan dan besarnya keluarga yang diinginkan. ${ }^{2}$

Beberapa metode atau alat kontrasepsi yang dapat digunakan wanita berdasarakan kandungan metode kontrasepsi terdiri atas kontrasepsi hormonal dan non hormonal. ${ }^{3}$ World Health Organization (WHO) memperkirakan hampir 380 juta pasangan yang menjalankan Program $K B$, 65-75 juta diantaranya, terutama di negara berkembang banyak menggunakan kontrasepsi hormonal seperti oral, suntik dan implant. ${ }^{4,5}$ Profil Indonesia 2017 menunjukkan dari 23.606.218 jumlah peserta KB aktif di Indonesia, 1.688 .685 orang peserta IUD $(7,15 \%), 655.762$ orang peserta MOW $(2,78 \%), \quad 124.262$ orang peserta MOP $(0,53 \%), \quad 1.650 .227$ orang peserta implant (6,69\%), 14.817 .663 orang peserta suntik $(62,77 \%), 288.388$ orang pengguna kondom $(1,22 \%)$, dan 4.069.844 orang pengguna pil $(17,24 \%)^{6}$

Jumlah pasangan usia subur di Sumatera Barat terdapat 729.430, diantaranya $\quad 57,17 \%$ merupakan akseptor $K B$ aktif dengan prevalensi $K B$ modern $56,78 \%$ dan pengguna jenis kontrasepsi suntik merupakan pengguna tertinggi dengan persentase $62,30 \%{ }^{6}$ Jumlah akseptor keluarga berencana aktif di Kota Padang yang menggunakan persentase tertinggi yaitu $48,85 \%$ akseptor kontrasepsi suntik. Akseptor KB suntik dengan pengguna terbanyak yaitu di Puskesmas Lubuk Buaya dan Puskesmas Andalas.

Menurut SDKI tahun 2017 kontrasepsi suntik merupakan metode kontrasepsi yang paling dikenal oleh responden dengan persentase $99 \%$. Namun tingkat putus pemakaian metode kontrasepsi suntik juga merupakan nomor dua tertinggi yaitu $28 \%$. Alasan putus pemakaian kontrasepsi yang paling tinggi yaitu karena akseptor takut efek samping atau masalah kesehatan yaitu $33 \%$ kemudian disusul dengan keinginan hamil $30 \%{ }^{8}$.

Penelitian yang dilakukan oleh Erna Setiawati, dkk tahun 2017 menyatakan bahwa distribusi kejadian efek samping yang timbul dalam pemilihan kontrasepsi tertinggi mengalami permasalahan kesehatan kenaikan berat badan yaitu 81 orang $(40,5 \%)$. $\mathrm{Hal}$ ini didukung dengan data dari SDKI tahun 2012 bahwa salah satu efek samping yang cukup banyak dikeluhkan akseptor KB yaitu peningkatan berat badan pada akseptor suntik sebesar $2,7 \%$ dari $10,6 \%$. $^{10}$

Peningkatan berat badan ini disebabkan oleh kandungan hormon yang terdapat pada kontrasepsi hormonal yang dapat merangsang pusat pengendalian nafsu makan sehingga akseptor makan lebih banyak dari pada biasanya. Hormon progesteron dapat mempermudah pengubahan karbohidrat dan gula menjadi lemak. Progesteron merangsang hipotalamus lateral sehingga makanan yang di makan oleh akseptor dengan cepat di rubah oleh progestin menjadi lemak, dan 
menurunkan aktivitas tubuh sehingga tidak terjadi proses pembakaran. Akibatnya terjadi penumpukan lemak di bawah kulit. Sedangkan hormon estrogen mengakibatkan bertambahnya lemaksubkutan, terutama pada pinggul, paha dan payudara, ini tampak setelah beberapa bulan penggunaan kontrasepsi."

Penelitian Wulandari menunjukkan untuk mengetahui perbedaan peningkatan berat badan antara akseptor kontrasepsi suntik satu bulan dan tiga bulan yang dilakukan pada 30 akseptor kontrasepsi suntik satu bulan dan 30 akseptor kontrasepsi suntik tiga bulan diperoleh nilai Asymp Sign (2tailed) sebesar 0,608 yang memiliki nilai lebih besar dari 0,05 yang menunjukkan tidak terdapat perbedaan yang signifikan dimana $93,3 \%$ responden suntik satu bulan mengalami peningkatan berat badan, demikian juga dengan responden suntik tiga bulan yang mengalami peningkatan berat badan sebanyak $93,3 \%$ responden.

Penelitian Atania dengan judul yang sama untuk mengetahui perbedaan peningkatan berat badan antara akseptor kontrasepsi suntik tiga bulan dan satu bulan menunjukkan kesimpulan terdapat perbedaan penambahan berat badan pada pengguna $K B$ suntik tiga bulan yang mengalami penambahan berat badan 34 atau $73,9 \%$ responden dari 46 orang. Pengguna KB suntik satu bulan yang mengalami perubahan berat badan 16 atau $34,8 \%$ responden. ${ }^{13}$

Penelitian Rosmala, dkk menunjukkan $77 \%$ pengguna kontrasepsi $>12$ bulan yang mengalami perubahan berat badan dan responden $<12$ bulan menggunakan kontrasepsi $72 \%$ yang tidak mengalami kenaikan berat badan. $^{14}$ Waktu lama pemakaian KB dapat mempengaruhi peningkatan berat badan karena semakin lama menggunakan KB suntik hormonal maka semakin meningkat berat badan karena pengaruh dari hormon progesteron yang meningkatkan nafsu makan dan menyebabkan tubuh kelebihan zat gizi. $^{15}$

Berdasarkan survey awal yang dilakukan peneliti dengan menggunakan teknik wawancara bebas kepada 10 orang akseptor keluarga berencana di wilayah kerja Puskesmas Andalas dengan proporsi 5 akseptor alat kontrasepsi suntikDMPAdan5akseptoralatkontrasep sisuntikKombinasi,didapatdari5 orang yang menggunakan alat kontrasepsi suntik DMPA, 4 orang mengalami kenaikan berat badan sebesar 2 sampai $5 \mathrm{~kg}$ selama 2 tahun pemakaian dan dari 5 orang yang menggunakan alat kontrasepsi suntikKombinasi, 4 orang mengalami kenaikan berat badan sebesar 2 sampai $8 \mathrm{~kg}$ selama penggunaan antara kurang dari 3 tahun.

\section{METODE}

Rancangan atau desain dalam penelitian ini adalah Cross sectional study, dengan jenis penelitiannya yaitu analitik komperatif. Penelitian dilaksanakan di wilayah kerja Puskesmas Andalas, Kota Padang pada tanggal 24 Januari sampai 21 Maret 2019. Populasi pada penelitian ini adalah semua akseptor KB aktif suntik Kombinasi dan suntik DMPA di wilayah kerja Puskesmas Andalas Kota Padang dari bulan Januari sampai Juni 2018 yang berjumlah 708 orang. Pengambilan sampel pada penelitian menggunakan teknik quota sampling. Sehingga didapatkan jumlah sampel sebanyak 62 Orang yang diambil berdasarkan perbandingan $1 ; 1$, maka 31 orang pengguna alat kontrasepsi 
suntik DMPA dan 31 orang pengguna alat kontrasepsi suntik Kombinasi. Analisis data univariat dengan distribusi frekuensi dan analisis data bivariat dengan uji T sampel independen.

\section{HASIL DAN PEMBAHASAN}

Hasil penelitian tentang perbedaan kenaikan berat badan wanita usia subur antara pengguna alat kontrasepsi suntik DMPA dan suntik kombinasi dapat disajikan sebagai berikut :

Tabel 1

Distribusi Frekuensi Karakteristik Responden Suntik KB DMPA dan Suntik kombinasi di wilayah keria Puskesmas Andalas Kota Padang Tahun

\begin{tabular}{llcc}
\multicolumn{4}{c}{2019} \\
\hline No & \multicolumn{1}{c}{ Karakter } & f & $\%$ \\
\hline & Usia: & & \\
$\mathbf{1}$ & $<20$ Tahun & 0 & 00,00 \\
$\mathbf{2}$ & 20 - 30Tahun & 17 & 27,40 \\
$\mathbf{3}$ & $31-$ 40Tahun & 36 & 58,10 \\
$\mathbf{4}$ & $41-$ 49Tahun & 9 & 14,50 \\
\hline & Pendidikan & & \\
$\mathbf{1}$ & SD & 8 & 12,90 \\
$\mathbf{2}$ & SMP & 12 & 19,40 \\
$\mathbf{3}$ & SMA & 34 & 54,80 \\
$\mathbf{4}$ & Akademi dan & 2 & 3,30 \\
& perguruan & 6 & 9,70 \\
& tinggi & & \\
\hline & Pekerjaan & & \\
$\mathbf{1}$ & Bekerja & 8 & 12,90 \\
$\mathbf{2}$ & Tidak bekerja & 54 & 87,10 \\
\hline
\end{tabular}

Berdasarkan tabel di atas diketahui responden terbanyak yaitu berjumlah 36 orang $(58,10 \%)$ dengan usia antara 31 40 tahun. Pendidikan responden terbanyak yaitu tamat SMA sebanyak 34 orang $(54,80 \%)$. Berdasarkan tabel di atas, responden terbanyak 54 orang $(87,10 \%)$, responden tidak bekerja/ lbu Rumah tangga.
Tabel 2

Distribusi Rata-Rata Lama Penggunaan Suntik KB DMPA dan Suntik kombinasi di wilayah keria Puskesmas Andalas Kota Padang Tahun 2019

\begin{tabular}{l|c|c|c}
\hline \multicolumn{1}{c|}{ Variabel } & $\begin{array}{c}\text { Mea } \\
n\end{array}$ & Min & Max \\
\hline $\begin{array}{l}\text { Lama PenggunaanAlat } \\
\text { Kontrasepsi(Tahun) }\end{array}$ & 3,53 & 1 & 10 \\
\hline $\begin{array}{l}\text { Berdasarkan tabel di atas dapat } \\
\text { diketahui bahwa rata-rata lama }\end{array}$
\end{tabular}
penggunaan alat kontrasepsi yaitu 3,53 tahun, dengan lama penggunaan terendah 1 tahun dan pengguna terlama 10 tahun.

Tabel 3

Distribusi Rata-Rata Kenaikan Berat Badan Penggunaan Suntik kombinasi di wilayah kerja Puskesmas Andalas Kota Padang Tahun 2019

\begin{tabular}{l|l|l|l}
\hline \multicolumn{1}{|c|}{ Variabel } & $\begin{array}{l}\text { Me } \\
\text { an }\end{array}$ & $\begin{array}{c}\mathrm{Mi} \\
\mathrm{n}\end{array}$ & $\begin{array}{l}\mathrm{M} \\
\mathrm{ax}\end{array}$ \\
\hline $\begin{array}{l}\text { Kenaikan berat badan } \\
\text { pengguna alat kontrasepsi } \\
\text { suntik kombinasi }\end{array}$ & 5, & 0 & 20 \\
& 77 & $\mathrm{~kg}$ & $\mathrm{~kg}$ \\
$\mathrm{~kg}$
\end{tabular}

Berdasarkan tabel di atas dapat diketahui rata-rata kenaikan berat badan pengguna suntik kombinasi yaitu sebesar $5,77 \mathrm{~kg}$ dengan kenaikan tertinggi $20 \mathrm{~kg}$.

Tabel 4

Distribusi Rata-Rata Kenaikan Berat Badan Penggunaan Suntik KB DMPA di wilayah kerja Puskesmas Andalas Kota Padang Tahun 2019

\begin{tabular}{l|l|c|l}
\hline \multicolumn{1}{|c|}{ Variabel } & Mean & $\begin{array}{c}\mathrm{Mi} \\
\mathrm{n}\end{array}$ & $\begin{array}{l}\text { Ma } \\
\mathrm{x}\end{array}$ \\
\hline $\begin{array}{l}\text { Kenaikan berat badan } \\
\text { pengguna alat } \\
\text { kontrasepsi suntik DMPA }\end{array}$ & $\begin{array}{l}7,29 \\
\mathrm{~kg}\end{array}$ & $\begin{array}{c}2 \\
\mathrm{~kg}\end{array}$ & $\begin{array}{l}19 \\
\mathrm{~kg}\end{array}$ \\
\hline
\end{tabular}

Berdasarkan tabel di atas dapat diketahui rata-rata kenaikan berat badan pengguna suntik DMPA yaitu sebesar $7,29 \mathrm{~kg}$ dengan kenaikan tertinggi $19 \mathrm{~kg}$. 
Tabel 5

Perbedaan Kenaikan Berat Badan Pengguna Alat Kontrasepsi Suntik KB Kombinasi dan Suntik DMPA di wilayah kerja Puskesmas Andalas Kota Padang Tahun 2019

\begin{tabular}{|c|c|c|c|c|c|}
\hline $\begin{array}{l}\text { Kenaikan } \\
\text { Berat Badan }\end{array}$ & $\begin{array}{c}\text { Mea } \\
n\end{array}$ & $\begin{array}{l}S \\
D\end{array}$ & $\mathrm{~T}$ & $\begin{array}{l}\text { Asym } \\
\text { p.Sig }\end{array}$ & $\mathrm{n}$ \\
\hline $\begin{array}{l}\text { Suntik } \\
\text { Kombinasi }\end{array}$ & $\begin{array}{c}5,77 \\
\mathrm{~kg}\end{array}$ & $\begin{array}{c}4, \\
1 \\
8 \\
5\end{array}$ & $\begin{array}{c}- \\
7,68 \\
2\end{array}$ & \multirow[t]{2}{*}{0,075} & $\begin{array}{l}3 \\
1\end{array}$ \\
\hline Suntik DMPA & $\begin{array}{c}7,29 \\
\mathrm{~kg}\end{array}$ & $\begin{array}{l}3 \\
7 \\
2 \\
6\end{array}$ & $\begin{array}{c}- \\
11,0 \\
18\end{array}$ & & $\begin{array}{l}3 \\
1\end{array}$ \\
\hline
\end{tabular}

Berdasarkan tabel di atas, rata-rata kenaikan berat badan pengguna alat kontrasepsi suntik kombinasi adalah 5,77 $\mathrm{kg}$ dengan standar deviasi 4,185. Berdasarkan hasil analisa perbedaan berat badan sebelum dan setelah penggunaan kontrasepsi suntik kombinasi dengan menggunakan uji t berpasangan (dependent t-test) didapatkan nilai $t$ sebesar -7,682 yang menunjukkan bahwa terdapat perbedaan berat badan sebelum dan sesudah penggunaan kontrasepsi suntik kombinasi dengan nilai Asymp.sig (2- tailed) sebesar 0,000 yang menunjukkan terdapat perbedaan yang signifikan.

Rata-rata kenaikan berat badan pengguna alat kontrasepsi suntik DMPA adalah $7,29 \mathrm{~kg}$ dengan standar deviasi 3,726 . Berdasarkan hasil analisa perbedaan berat badan sebelum dan setelah penggunaan kontrasepsi suntik DMPA dengan menggunakan uji $t$ berpasangan (dependent t-test) didapatkan nilai t sebesar $-11,018$ yang menunjukkan bahwa terdapat perbedaan berat badan sebelum dan setelah penggunaan kontrasepsi suntik DMPA dan nilai Asymp.sig (2-tailed) sebesar 0,000 yang menunjukkan terdapat perbedaan yangsignifikan.

Hasil analisa data terhadap perbedaan peningkatan berat badan antara akseptor KB suntik kombinasi dan DMPA dengan menggunakan Mann Whitney Test didapatkan nilai Asymp. Sig (2tailed) sebesar 0,075 yang menunjukkan terdapat perbedaan yang tidak signifikan, sehingga dapat disimpulkan bahwa tidak ada perbedaan peningkatan berat badan antara akseptor KB suntik kombinasi dan akseptor KB suntik DMPA di wilayah kerja Puskesmas Andalas Kota Padang Tahun 2019.

Pemakaian kontrasepsi suntik kombinasi (suntik 1 bulan) mempunyai efek samping utama yaitu perubahan berat badan. Hal ini disebabkan karena suntik satu bulan mengandung kombinasi hormon progesteron dan estrogen atau medroksiprogesteron asetat sebanyak $50 \mathrm{mg}$ dan estradiol spionat $10 \mathrm{mg}$ tiap kali injeksi. Hormon progesteron merangsang hormon nafsu makan yang ada di hipotalamus, ${ }^{15}$ hormon estrogen menyebabkan terjadinya peningkatan pengendapan lemak pada mammae dan jaringan subkutis, pengendapan lemak pada pantat, paha dan menyebabkan pelebaran panggul.'

Peningkatan berat badan pada pengguna kontrasepsi suntik bulanan atau suntik kombinasi mempunyai efek yang cukup ringan, rata-rata penambahan berat badan dua hingga tiga kilogram pada tahun pertama pemakaian dan terus meningkat pada tahun berikutnya. ${ }^{11}$ Dari penjelasan diatas dapat disimpulkan bahwa ada perbedaan berat badan sebelum dan setelah penggunaan kontrasepsi suntik kombinasi, hal ini juga ditunjukkan dari hasil penelitian dengan menggunakan uji t berpasangan (dependent t- test) didapatkan nilai $t$ sebesar $-7,682$ yang menunjukkan bahwa terdapat perbedaan berat badan sebelum dan setelah penggunaan kontrasepsi suntik kombinasi dan nilai Asymp.sig (2-tailed) sebesar 0,000 yang menunjukkan terdapat perbedaan yang signifikan. 
Pemakaian kontrasepsi suntik DMPA (suntik 3 bulan ) mempunyai efek samping utama yaitu perubahan berat badan. Hal ini disebabkan karnakontrasepsi suntik DMPA mengandung hormon progesteron atau medroksiprogesteron sebanyak $150 \mathrm{mg}$ dalam bentuk kecil. ${ }^{3}$ Hormon progesteron yang kuat mampu merangsang hormon nafsu makan yang ada di hipotalamus. Dengan adanya nafsu makan yang lebih banyak dari biasanya tubuh akan kelebihan zat-zat gizi. Kelebihan zat-zat gizi oleh hormon progesteron dirubah menjadi lemak dan disimpan dibawah kulit. Perubahan berat badan ini akibat adanya penumpukan lemak yang berlebih hasil sintesa dari karbohidrat menjadi lemak. $^{15,17}$

Hal ini sesuai dengan teori yang Glasier (2005) yang menyatakan selama enam bulan pertama pemakaian kontrasepsi DMPA akan terjadi peningkatan berat badan sebesar 1,3 kg, kemudian didukung oleh teori Cunningham (2006) penambahan berat badan rata-rata 2,7 $\mathrm{kg}$ pada tahun pertama, dan terus bertambah pada tahun berikutnya. Penelitian oleh Univercity of Texas Medical Branch (UMBT), didapatkan bahwa wanita yang menggunakan kontrasepsi DMPA atau dikenal dengan Suntik 3 bulan, rata-rata mengalami peningkatan berat badan sebanyak 5,5 kg dalam waktu 3 tahunpemakaian. 15,16 Hasil penelitian berdasarkan analisa perbedaan berat badan sebelum dan setelah penggunaan kontrasepsi suntik DMPA dengan menggunakan uji $t$ berpasangan (dependent t-test) didapatkan nilai $t$ sebesar $-11,018$ yang menunjukkan bahwa terdapat perbedaan berat badan sebelum dan setelah penggunaan kontrasepsi suntik DMPA dan nilai Asymp.sig (2-tailed) sebesar 0,000 yang menunjukkan terdapat perbedaan yang signifikan.
Maka dapat disimpulkan ada perbedaan yang signifikan antara berat badan sebelum dan setelah penggunaan kontrasepsi suntik DMPA. Penelitian ini sejalan dengan hasil penelitian Pratiwi, dkk (2013) berdasarkan analisis dengan uji $T$ didapatkan bahwa terdapat hubungan antara kontrasepsi hormonal suntik DMPA dengan peningkatan berat badan akseptor $K B, p$-value $=0,000$ lebih kecil dari $\alpha=0,05$ yang menunjukkan adanya perbedaan ratarata berat badan awal dan akhir. ${ }^{18}$ Irianingsih tahun 2011 juga melakukan penelitian mengenai hubungan lama pemakaian $K B$ suntik DMPA dengan peningkatan peningkatan berat badan pada peserta KB di Puskesmas Klego II Kabupaten Boyolali. Dari penelitian ini diperoleh hasil bahwa akseptor KB suntik DMPA yang menggunakan lebih dari 1 tahun lebih berisiko mengalami kenaikan berat badan lebih besar dibanding akseptor yang menggunakan kurang dari 1 tahun.

Berdasarkan hasil analisa data terhadap peningkatan berat badan pada akseptor KB suntik DMPA dan suntik kombinasi dengan menggunakan uji Mann Whitney Test untuk mengetahui perbedaan peningkatan berat badan antara akseptor suntik DMPA dan akseptor suntik Kombinasi yang dilakukan pada 31 akseptor kontrasepsi suntik DMPA dan 31 akseptor suntik Kombinasi diperoleh nilai Asymp. Sig (2tailed) sebesar 0,075 yang memiliki nilai lebih besar dari a penelitian $(0,05)$, yang menunjukkan tidak terdapat perbedaan yang signifikan. Maka Ha ditolak, sehingga diperoleh hasil tidak ada perbedaan antara peningkatanberatbadan akseptor suntik DMPA dengan akseptor suntik Kombinasi. Hasil penelitian menunjukkan tidak ada perbedaan kenaikan berat badan yang signifikan antara antara 
pengguna suntik DMPA dengan suntik kombinasi pada wanita pasangan usia subur di wilayah kerja Puskesmas Andalas KotaPadang.

Penelitian ini juga didukung oleh penelitian wulandari untuk mengetahui perbeadaan peningkatan berat badan antara akseptor KB suntik 1 bulan dengan tiga bulan didapat nilai Asymp Sig (2-Tailed) sebesar 0,608 yang menunjukkan tidak terdapat perbedaan kenaikan berat badan yang signifikan antara pengguna suntik satu bulan dengan pengguna suntik tigabulan. ${ }^{12}$

Pemakaian kontrasepsi suntik baik DMPA maupun Kombinasi mempunyai efek samping utama yaitu penambhan berat badan. Faktor yang mempengaruhi perubahan berat badan akseptor KB suntik adalah kandungan hormon progesteron yang kuat sehingga merangsang hormon nafsu makan yang ada di hipotalamus. ${ }^{15}$ Sedangkan, hormon estrogen menyebabkan terjadinya pengendapan lemak pada mammae dan jaringan subkutis, pengendapan lemak pada pantat, paha dan menyebabkan pelebaran panggul, sehingga mengakibatkan penambahan berat badan. ${ }^{11}$

Peningkatan berat badan yang didapat dari hasil penelitian memiliki nilai yang bervariasi. Hal ini disebabkan karena banyak faktor-faktor lain yang mempengaruhi berat badan yang tidak diamati dalam penelitian ini. Faktorfaktor lain seperti genetik, jenis pekerjaan, kegiatan atau aktivitas sehari-hari, pola konsumsi makanan, dan lain sebagainya juga mempengaruhi berat badan seseorang. Sampai saat ini belum tersedia $100 \%$ metode kontrasepsi yang sempurna dan ideal tentu saja ada efek samping, begitu juga dengan alat kontrasepsi suntik. ${ }^{11}$ Pengaturan diet dan aktivitas fisik masih menjadi tata laksana utama kegemukan. Kualitas asupan diperbaiki dengan mengurangi konsumsi makanan padat energi contohnya makanan yang tinggi lemak dan gula, serta dengan meningkatkan asupan serat. ${ }^{19}$

\section{SIMPULAN}

Rata-rata kenaikan berat badan pengguna alat kontrasepsi suntik kombinasi adalah $5,77 \mathrm{~kg}$. Ada perbedaan yang signifikan antara berat badan sebelum dan setelah penggunaan kontrasepsi suntik Kombinasi di wilayah kerja Puskesmas Andalas Kota Padang tahun 2019. Rata-rata kenaikan berat badan pengguna alat kontrasepsi suntik DMPA adalah $7,29 \mathrm{~kg}$. Ada perbedaan yang signifikan antara berat badan sebelum dan setelah penggunaan kontrasepsi suntik DMPA di wilayah kerja Puskesmas Andalas Kota Padang tahun 2019. Tidak ada perbedaan yang signifikan rerata peningkatan berat badan antara akseptor $K B$ suntik kombinasi dan akseptor KB suntik DMPA di wilayah kerja Puskesmas Andalas Kota Padang tahun 2019.

\section{DAFTAR PUSTAKA}

[1] Bkkbn. Review Program Kependudukan, Keluarga Berencana, Dan Pembangunan Keluarga (KKBPK) Tahun 2017. Provinsi Sumatera Barat: Bkkbn; 2017.

[2] Maryani. Buku Panduan Pelayanan Kontrasepsi. Jakarta:Rineka Cipta; 2009

[3] Manuaba,I. Memahami Kesehatan Reproduksi Wanita. Edisi 2.Jakarta: Penerbit BukuKedokteran;2009

[4] Baziat,A. Kontrasepsi Hormonal. Jakarta: Yayasan Bina Pustaka SarwonoPrawirohardjo;2009

[5] Meril RM. Epidemiologi Reproduktif. Jakarta:EGC;2013

[6] Kementrian Kesehatan RI. Data dan Profil Kesehatan Indonesia tahun 2017.Jakarta;2018 
7] Dinas Kesehatan Kota Padang. Situasi Derajat Kesehatan. Padang: Profil Kesehatan Kota Padang;2017.

[8] Kementrian Kesehatan RI. Preliminary Report Survey

DemografiKesehatan lindonesia tahun 2017. Jakarta;2018

[9] Setiawati, E., Handayani, O. W. K. \& Kuswardinah, A. Pemilihan Kontrasepsi Berdasarkan Efek Samping Pada Dua Kelompok Usia Reproduksi. Unnes J. ofPublic Heal. 6, 167-173(2017).

[10] BKKBN \& Kemenkes. Survei Demografi dan Kesehan Indonesia tahun 2012. Jakarta;2013.doi:0910383107[pii ] $\backslash r 10.1073 /$ pnas.0910383107

[11] Hartanto,H. Keluarga Berencana dan Kontrasepsi.Jakarta: Pustaka Sinar Harapan;2010

[12] Wulandari,PP. Perbedaan Peningkatan Berat Badan Antara Akseptor Kontrasepsi Satu Bulanan dan Tiga Bulanan Di Puskesmas II Denpasar selatan. No Title. 1-7: Bali; Universitas Udayana2010.

[13] Rachma, A. \& Widatiningsih, S. Perbedaan Penambahan Berat Badan Pada Akseptor Kontrasepsi Suntik 3 Bulan Dengan 1 Bulan Di Kelurahan Karang Kidul Kecamatan Magelang Selatan Kota Magelang. J. Kebidanan 5, 39-48(2016).

[14] Nur, R. \& Rahman, A. Use of Contraception and Change in Weight on Family Planning Acceptor . 1, 131-140 (2017).

[15] Masjoer,arif. Kapita Selekta Kedokteran. Jakarta: Media Aesculpalus; 2010

[16] Rosmadewi. Perbedaan Kenaikan Berat Badan Wanita Usia Subur Antara Pengguna Alat Kontrasepsi Pil Dan Suntik. XI, 329334.Lampung: Poltekkes Tanjung Karang; 2015.

[17] Oktaviary, C. \& Wagiyo. Efek
Penggunaan Alat Kontrasepsi Pil Dan Suntik 3 Bulan Terhadap Status Gizi Dan Tekanan Darah Pada Akseptor $\mathrm{Kb} \quad \mathrm{Di}$ Puskesmas Kedungmundu Semarang.Semarang: Poltekkes Kemekes Semarang;2015.

[18] Pratiwi, Syahredi \& Erkadius. Hubungan Antara Penggunaan Kontrasepsi Hormonal Suntik DMPA dengan Peningkatan Berat Badan di Puskesmas Lapai Kota Padang. Padang; Universitas Andalas (2013)

[19] Irianingsih, H. Hubungan Lama Pemakaian KB Suntik 3 Bulan Depo Progestin dengan Peningkatan Berat Badan pada Akseptor KB di Puskesmas Klego II Kabupaten Boyolali. Surakarta; Skripsi, Fakultas Kedokteran, Universitas Muhammadiyah Surakarta. (2011). 